\title{
MITIGATING CLIMATE CHANGE THROUGH ENERGY EFFICIENT PRACTICES IN HIGH ALTITUDES OF NEPAL
}

\author{
Silu Bhochhibhoya \\ Ramesh Kumar Maskey \\ Sanjaya Nath Khanal \\ Centre for Excellence in Production and Transportation of Electrical Energy, \\ Kathmandu University, Nepal
}

\begin{abstract}
Climate change is a global scale crisis with drastic effects on higher altitudes. Ice melting and its corresponding impacts on mountain ecosystems are just some of the most directly visible signals of global warming. Increased rate of energy consumption, emissions along with ever growing tourist inflow in such areas has a high impact on this phenomenon. Particulate matter, Carbon Dioxide and Methane are some of the chief emissions in such areas with negative impact on the environment. Since burning of fossil fuels is one of the main root causes of cclimate change, its risk mitigation and adaptation depends greatly on energy conservation and the use of renewable energy technologies. Well insulated energy - efficient building construction method and the increased use of renewable energy sources could be the key solution. Reduction of dung-cakes and kerosene for space heating would decrease the greenhouse gas emissions as well as black carbons and particulate matters and improves the indoor living conditions. Energy efficient technologies including the building of traditional Sherpa houses could be the best practice to reduce the impact of climate change in high altitudes. This paper is primarily concerned with testing the thermal properties of insulating tiles made of locally available materials as well as to establish a correlation between energy consumption patterns in different building types with respective $\mathrm{CO}_{2}$ emissions. Subsequently, the positive attributes of such energy conserving design in relation to climate change adaptation is ascertained.
\end{abstract}

KEYWORDS: Energy-efficient buildings, Energy Use, Insulating materials, Sagarmatha National Park

\section{INTRODUCTION}

Energy is essential for social and economic development and the improvement of living standard. Various energy sources are being explored by human society to fulfil its energy needs. However, biomass, particularly fuel-wood, is the main source of energy for cooking, space heating and water heating in rural households of developing countries [1].

On account of the exponential rise in human population, there is a tremendous pressure on forest lands, resulting in their degradation and heavy depletion of the resource. The situation is particularly serious in the fragile Himalayan ecosystem, which is facing large-scale deforestation and soil erosion [2]. High exploitation of energy-use could place a significant https://doi.org/10.15626/Eco-Tech.2010.081 
damage both on environment and human health by $\mathrm{CO}_{2}, \mathrm{CH}_{4}, \mathrm{CO}, \mathrm{SO}_{2}, \mathrm{NO}_{\mathrm{x}}$ effluent gas emissions. Scientists believe that one of the main causes of climate change is the emission of greenhouse gases into the atmosphere due to the increased use of fossil fuels. The mitigation of climate change and thereby increasing the adaptability for such change mainly depends on the increased use of energy efficient and renewable energy technologies [3].

Green house gas (GHG) emission due to inefficient combustion of traditional (fuel wood, cattle dung-cake) and commercial (kerosene, Liquid Petroleum Gas) energy sources can be decreased using efficient energy technologies. In this context, the study on energy- efficient building construction technology and the use of renewable energy sources in Sagarmatha National Park and Buffer Zone (SNPBZ) as well as Langtang National Park and Buffer Zone (LNPBZ) was conducted in 2007-2008 and 2009-2010 respectively. In the subsequent paragraphs, a detailed description of study the in SNPBZ is given and the relevant data from LNPBZ is taken for comparison. A brief description on the test conducted to find the thermal properties of the insulating tiles made of local materials is also given to show the usefulness of these tiles for reducing energy consumption in mountainous regions.

\section{STUDY AREA}

SNPBZ is situated in Solu-Khumbu District of Sagarmatha Zone in the north-eastern regions of Nepal. Its altitude ranges from $2800 \mathrm{~m}$ to $8848 \mathrm{~m}$ above mean sea level. It is a popular tourist destination because of its bountiful natural beauty enhanced by highest peaks of the world. This area attracts about 21000 tourists each year [4]. Due to high tourist influx and the lack of enough energy supply from renewable sources, the use of conventional energy sources are very intensive in SNPBZ producing high amount of GHG emission.

In the Park, large amount of energy is used for space heating due to severe cold winter. The energy consumption of 3372 GJ is consumed per year for space heating in winter [5]. Maximum and minimum yearly mean temperature is less than 12 degree and -6 degree Celsius respectively [6].

In general, energy used for space heating is higher for buildings with low insulation capacity. If the buildings were poorly insulated, a great deal of heat will escape that demands more energy to keep it warm in winter. In order to reduce the use of energy that is unnecessarily being wasted, there is a need to insulate the building properly. It has been found that the traditional Sherpa buildings are thermally more efficient than the modern and semi-modern buildings in SNPBZ areas. Thus, this paper will mainly deals with the investigating the insulating property, i.e. a lower thermal transmittance ( $U$ - value) of tiles made of locally available construction materials and waste such as plastics, papers, wooden grain and white clay and their potentiality for reducing green house gas emission from thermally insulated building.

As part of study financed by Ev-K2-CNR, energy management model was developed, which showed that the yearly energy deficit at the park level (all energy sources considered) is around 7 percent of the demand $(4000 \mathrm{kWh})$. Reduction of this energy deficit can contemplate the implementation of management policies in the energy model: the introduction of energy-saving lamps and the improvement of insulation could make energy surplus by 7 percent [7]. 
This is a positive approach toward mitigation of climate change. Energy efficient technologies could be one of the best practices in the Himalayan region like SNPBZ in order to reduce the use of energy that ultimately minimizes the green house gas emission. This study analyzes the contribution of Traditional Sherpa building practice as one of the good examples of well insulated houses in mountainous regions.

\section{FIELD STUDY RESULT}

\subsection{Energy-use and $\mathrm{CO}_{2}$ emission}

Emission of pollutants from the use of biomass fuels depends on the quantities of the fuels consumed. However, it is equally dependent upon the type and efficiency of space heater used. Thus increase in efficiency of the space heater will also reduce emission from biomass use and its amount [8].

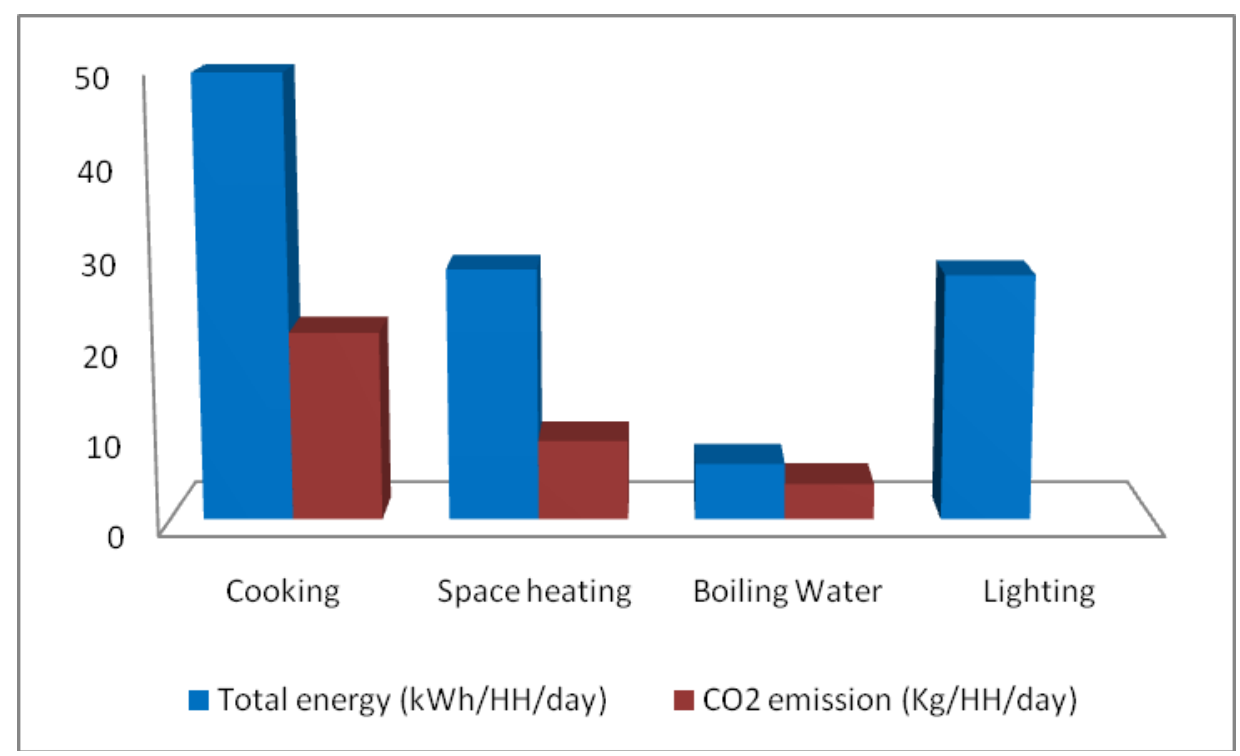

Figure 3.1: CO2 emission from different household activities

The study estimated that high amount of energy is utilized for cooking see figure 3.1 . Cooking composed of 64 percent of total energy [9]. Fuel wood and kerosene which produce more GHG emission compare to LPG are the major energy source for cooking. Some quantity of LPG and electricity are also used for this purpose. Since the total quantity of fuel is high, increase in GHG emission is also high. The emission of pollutant is high from cooking. By increasing the efficiency of cooking stove, the emission of GHG can be reduced. According to Sulpya, the efficiency of cooking stove is $16.1 \%$ in Namche [10].

In terms of utilization of energy, space heating rank second position consuming 23 percent of total energy. Fuel wood and dung are the primary source for space heating [11]. Emission of greenhouse gases depends on quantity and types of energy used. Similarly for boiling water, emission of GHG is less as it consumed less energy. 
Emission of pollutants from fuel wood and cattle dung for space heating can be reduce by increasing efficiency on house building or by increasing the efficiency of the stove. This paper mainly deals with efficient thermal buildings to reduce the heat demand to warm the room. From our study it was estimated that energy utilization for space heating lies in the second rank after cooking. Therefore, energy usages for space heating can be reduce by increasing the efficiency of house building to reduce the heat loss from the building.

\subsection{Potentiality for Reducing Green-house Gas}

Well insulated building reduces the heat demand thus reducing the $\mathrm{CO} 2$ emission. Reduction in heat demand in a house depends on the type of insulation used. Since the different insulating materials have different thermal conductivities, there will be slight variation in Uvalue and thus with their performance.

Owner's selection of insulation material determines the amount of heat loss and thus the energy demand for heating. They are therefore having a choice of using expensive glass wool or locally available mud plaster and thermocole, reducing a heat demand by $23 \%$ and $20 \%$ respectively. Initial investment in insulation could save the unnecessary future expense in energy. The installation of insulation using locally available resource has least payback period than using other resources available for insulation.

The existing energy demand and supply along with the energy demand after using proper insulation like wooden plank, mud plastering and thermocole (see Figure 3.2). Also shown is the total $\mathrm{CO} 2$ emission from the corresponding energy demand.

The total consumption of energy for space heating is $935028 \mathrm{kWh}$ per year in SNPBZ. The use of proper insulation will reduce the consumption into $579717 \mathrm{kWh}$.

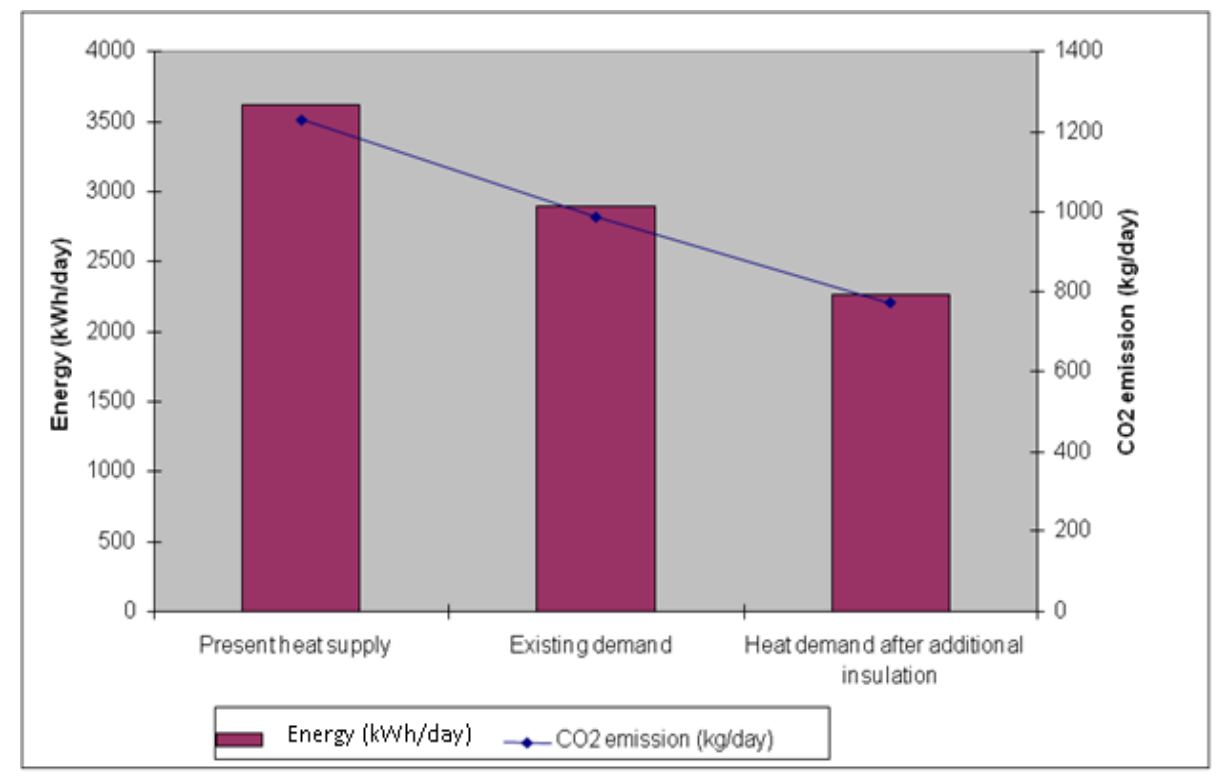

Figure 3.2: Reduced CO2 emission through insulation (Bhochhibhoya, et al.,2008) 
The estimation shows that the $\mathrm{CO}_{2}$ emission can be reduced by $19 \%$, while reducing present energy consumption. It also indicates potentiality for reducing $\mathrm{CO}_{2}$ by $38 \%$ while maintaining the energy supply to the demand limit after use of proper insulation.

\subsection{Patterns of Space Heating in Buildings}

This study shows that the modern building, which uses the imported construction materials with heavy insulation, are more energy efficient as it only needs only $13 \mathrm{~W} / \mathrm{m} 3$ to keep the room in comfortable temperature. Use of imported insulating material in the wall and the modern glass technology has reduced the energy consumption as compared to traditional and medium modified houses for space heating, which results in less energy demand in these houses (see Figure 3.3).

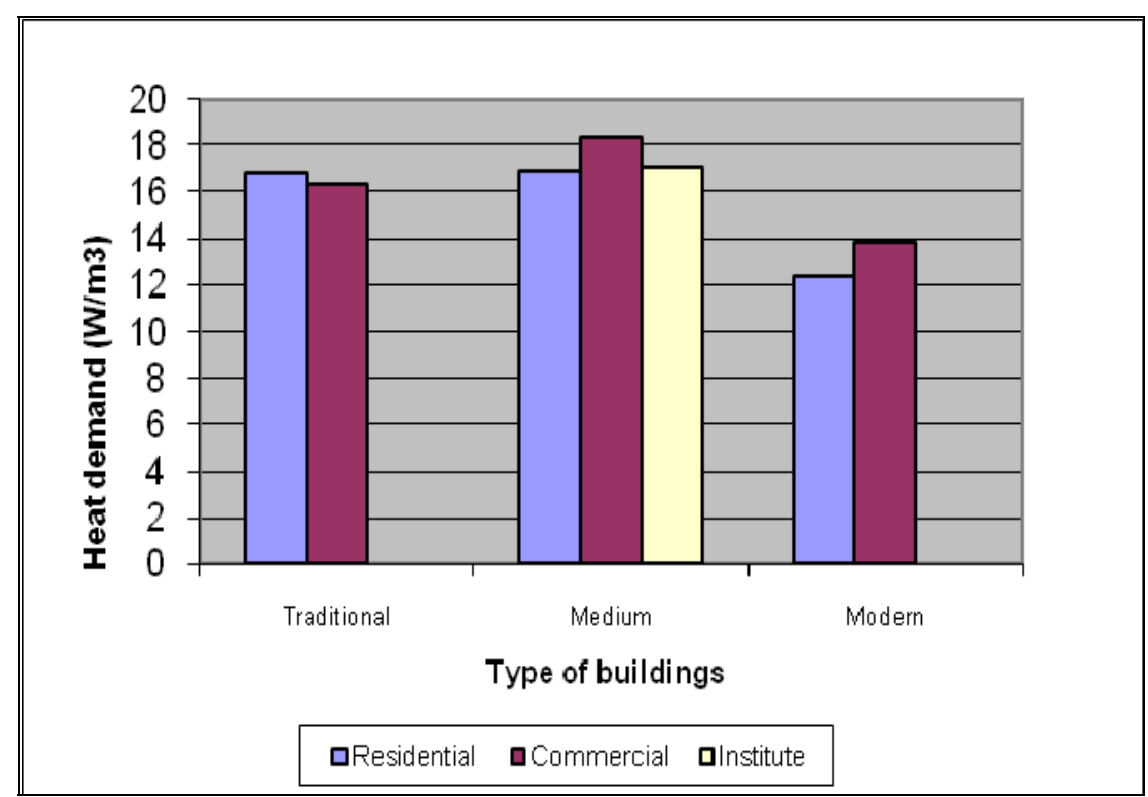

Figure 3.3: Energy-use for space heating (Bhochhibhoya, et al.,(2008)

Traditional buildings "Sherpa Houses", which follow their ancestral house design practice, having thick wall with mud plaster demands $16.6 \mathrm{~W} / \mathrm{m} 3$ of energy to keep room warm. Traditional residential building are found to have living room and kitchen room in the same place or are found to be adjoining. This results in radiation of cooking heat towards the surrounding which in turn keeps the living room warm.

The semi-modern type houses made up of both the combination of the local and modern technologies with limited insulation demand $17.44 \mathrm{~W} / \mathrm{m} 3$ energy for space heating. These houses are usually made of thin wall and lack of proper insulation as compared to modern and traditional Sherpa houses. The heat demand is therefore high in these building whether it is for residential, commercial or institutional. 


\subsection{Comparison of Heat Demand of building in Langtang National Park and Buffer Zone (LNPBZ) and Sagarmatha National park and Buffer Zone (SNPBZ)}

The study done on high altitude of Nepal shows that high amount of heat is required to warm the room. LNPBZ and SNPBZ are high altitude national park which are highly popular tourist destination.

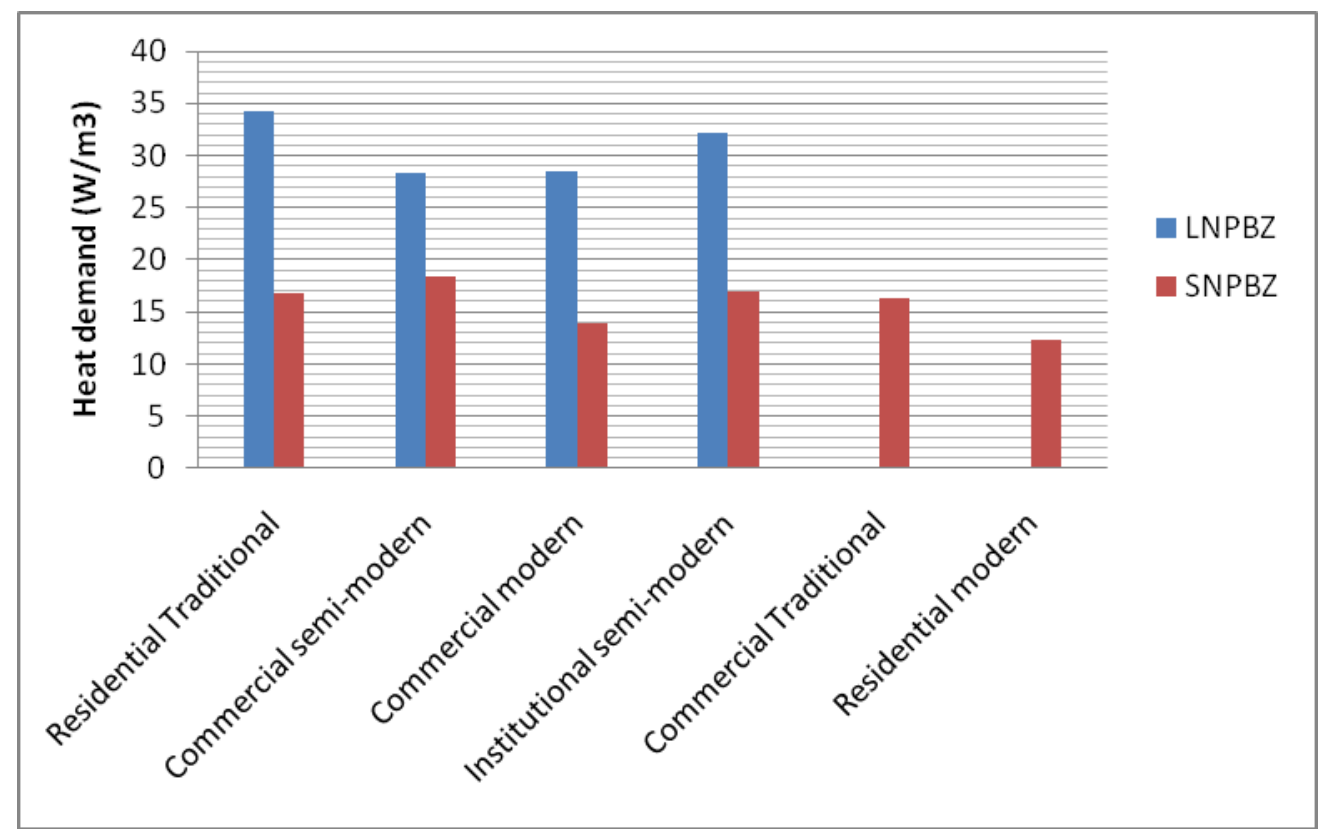

Figure 3.4: Heat demand of building in LNPBZ and SNPBZ (Dahal et al., 2009 for Langtang data)

Various types of building in LNPBZ acquired high amount of heat rather than SNPBZ to keep the room warm (see figure 3.4). Residential traditional type of building of LNPBZ required 34 $\mathrm{W} / \mathrm{m} 3$ of energy whereas only $17 \mathrm{~W} / \mathrm{m} 3$ of energy is enough to keep the room warm in SNPBZ. Modern buildings of SNPBZ are more energy efficient as it used imported construciton materials with heavy insulation. However, modern and semi-modern buildings of LNPBZ are less efficient.

\section{PREPARATION OF TEST MATERIALS AND RIG}

The insulation tiles from locally available materials like Kamero (white clay), cow dung and waste product like plastic, paper, wooden grain, rice husk were made to test the thermal transmittance (U- value) (see Figure 4.1). The tiles were prepared by mixing with one part dung, two part fillers (viz. plastic, paper, wood grains) and 4 part Kamero. 


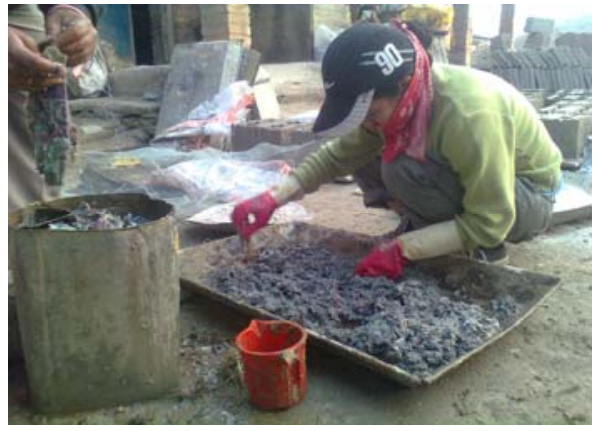

Figure 4.1: Preparation of material

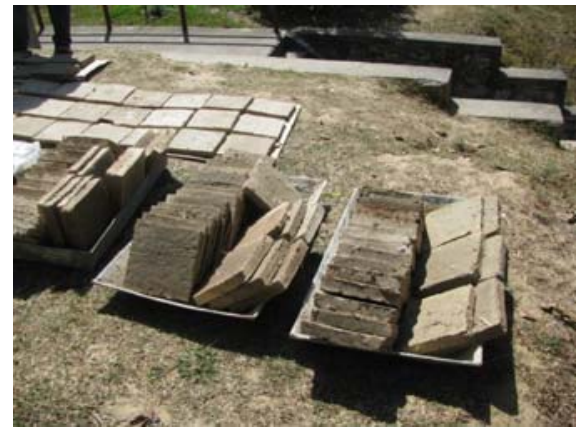

Figure4.2: Insulation brick
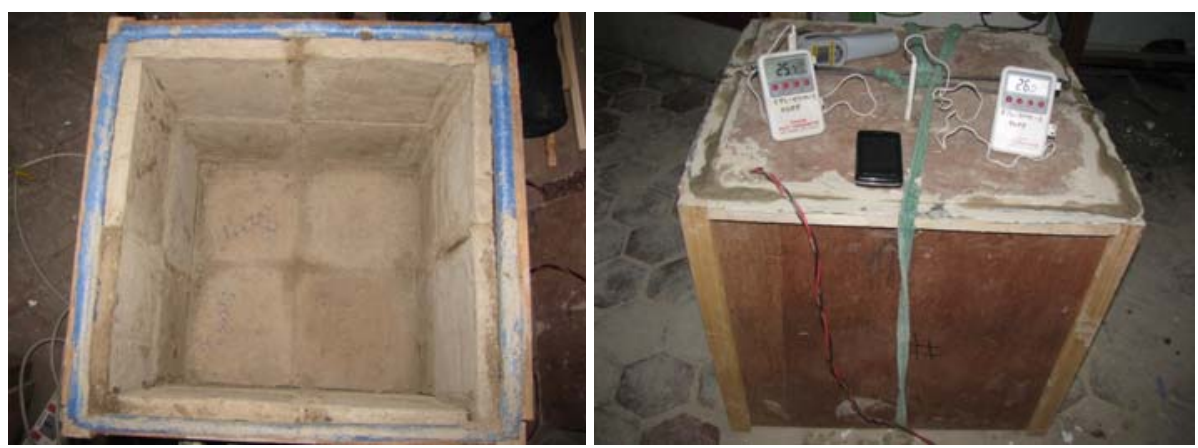

Figure 4.3: Testing of the insulation brick

The produced tiles are of dimensions $(230 \mathrm{~mm}$ X $230 \mathrm{~mm}$ X $51 \mathrm{~mm})$ shown in figure 4.2. Thermal properties of the tiles were studied in the hot box of size $(510 \mathrm{mmX} 510 \mathrm{~mm}$ X 510 $\mathrm{mm}$ ) (see Figure 4.3). The Styrofoam with the known thermal conductivity was used for the calibration of the hot box which results 83 percent efficient. One $\mathrm{kW}$ of heat source was applied to raise the inside temperature of the box from $18^{\circ} \mathrm{C}$ to $140{ }^{\circ} \mathrm{C}$ for a period of 30 min. The outside temperature of the box was recorded $17^{\circ} \mathrm{C}$. The data obtained were stored and analyzed in Microsoft Excel.

\section{FINDINGS AND DISCUSSION}

\subsection{Retaining Temperature}

The average temperature in the hot box with the insulation tiles increases drastically within few minutes and the rate of loss of temperature is slow. The temperature remains in the comfortable zone) i.e. $25^{\circ} \mathrm{C}$ for longer period of time (see Figure 5.1). 
Linnaeus ECO-TECH '10

Kalmar, Sweden, November 22-24, 2010

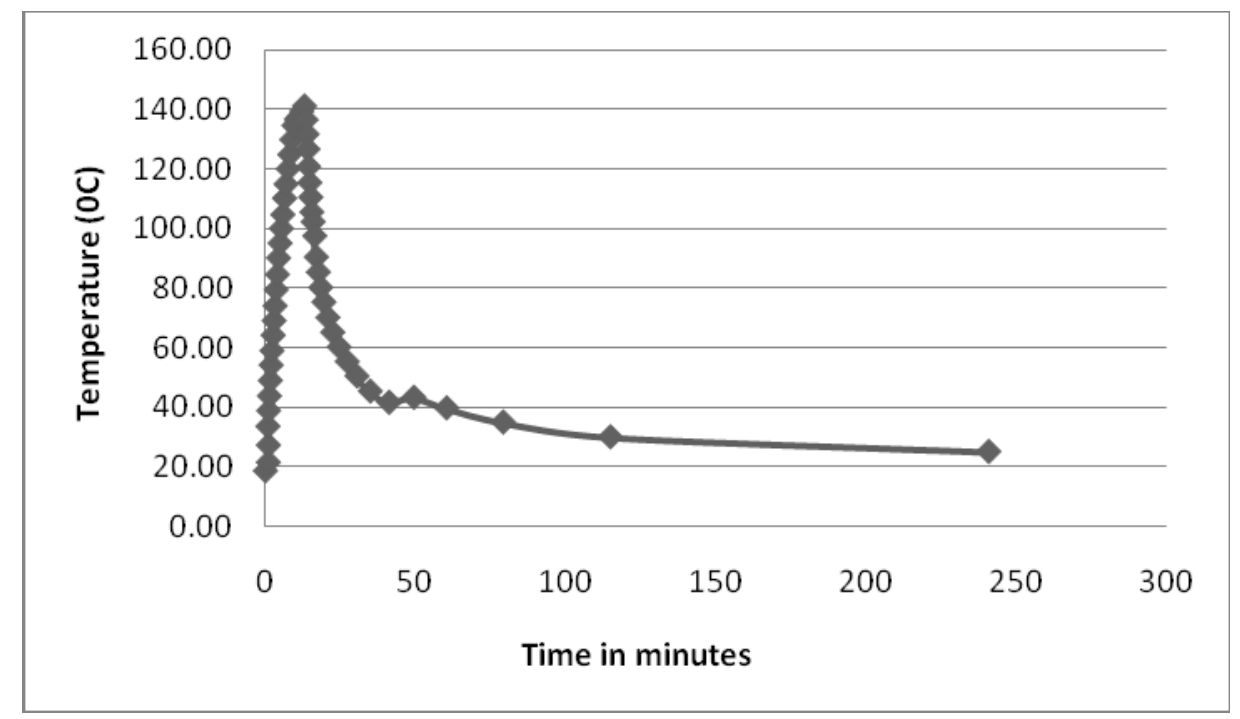

Figure 5.1: Retained Temperature

The graph indicates that the insulation tiles can retain heat supply of $30 \mathrm{~min}$ for a period of four hours in comfortable temperature. Thus, the temperature gradient is very high indicating the effectiveness of the insulating tile to retain the temperature. However, the effect of low temperature outside the box should be considered for the performance test of the tiles, which is the subject of further research.

\subsection{Efficiency of Insulation Material made up of Abundantly Available Material}

The thermal transmittance (U- Value) of different types of tiles depends on their physical properties and its thickness. The U- Values of different types of tiles made up of locally available cum waste products are see table 5.1. The tile of kamero (white clay), cow dung and paper pulp with $0.032 \mathrm{~m}$ thickness has a lowest U-Value of $2.370 \mathrm{~W} / \mathrm{m}^{2} \mathrm{~K}$. The tile of kamero (white clay), wooden grain, plastic thread, cow dung with thickness $0.032 \mathrm{~m}$ comes in second rank as it has a U-Value $2.413 \mathrm{~W} / \mathrm{m}^{2} \mathrm{~K}$. 
Table 5.1: Thermal Efficiency of tiles

\begin{tabular}{|l|c|c|c|c|}
\hline Types of insulating material & $\begin{array}{l}\text { Thickness } \\
\mathbf{( m )}\end{array}$ & $\begin{array}{c}\text { Thermal } \\
\text { Conductivity } \\
\mathbf{( W / m K})\end{array}$ & $\begin{array}{c}\mathbf{R} \\
\left(\mathbf{m}^{2} \mathbf{K} / \mathbf{W}\right)\end{array}$ & $\begin{array}{c}\mathbf{U} \\
\left(\mathbf{W} / \mathbf{m}^{2} \mathbf{K}\right)\end{array}$ \\
\hline Empty box & 0.025 & 1.023 & 0.046 & 41.056 \\
\hline Styrofoam & 0.032 & 0.078 & 0.402 & 2.521 \\
\hline Option 1(Kamero, Wooden grain, cow dung) & 0.025 & 0.092 & 0.281 & 3.633 \\
\hline $\begin{array}{l}\text { Option 7 (Kamero, Wooden grain, plastic } \\
\text { thread, cow dung) }\end{array}$ & 0.032 & 0.075 & 0.423 & 2.413 \\
\hline Option 2 (Kamero, Rice husk, cow dung) & 0.025 & 0.094 & 0.275 & 3.734 \\
\hline $\begin{array}{l}\text { Option 10 (Kamero, Brick powder, cow } \\
\text { dung) }\end{array}$ & 0.025 & 0.096 & 0.275 & 3.639 \\
\hline Option 13 (Kamero, paper pulp, cow dung) & 0.032 & 0.075 & 0.427 & 2.370 \\
\hline $\begin{array}{l}\text { Option 11 (Kamero, paper pulp, cow dung, } \\
\text { baking powder) }\end{array}$ & 0.025 & 0.089 & 0.296 & 3.439 \\
\hline
\end{tabular}

The U-value of empty box is $41.056 \mathrm{~W} / \mathrm{m}^{2} \mathrm{~K}$ whereas Styrofoam has its U- value 2.521 $\mathrm{W} / \mathrm{m}^{2} \mathrm{~K}$ in the model room.

\subsection{Comparison of Cost of Insulation Tiles made of Various Materials}

Lesser the U-value more efficient the insulation material is. The commercial insulation material like Plywood has a high U- value as well as the high cost of the material. Thermocole and glass wool is relatively better insulation materials due to low U-value but have higher cost. On the other hand, insulation tile made up of locally available material have lesser Uvalue and comparatively lower cost than other materials (see Figure 5.2). In this comparison, the cost of transportation to the site is not considered. 


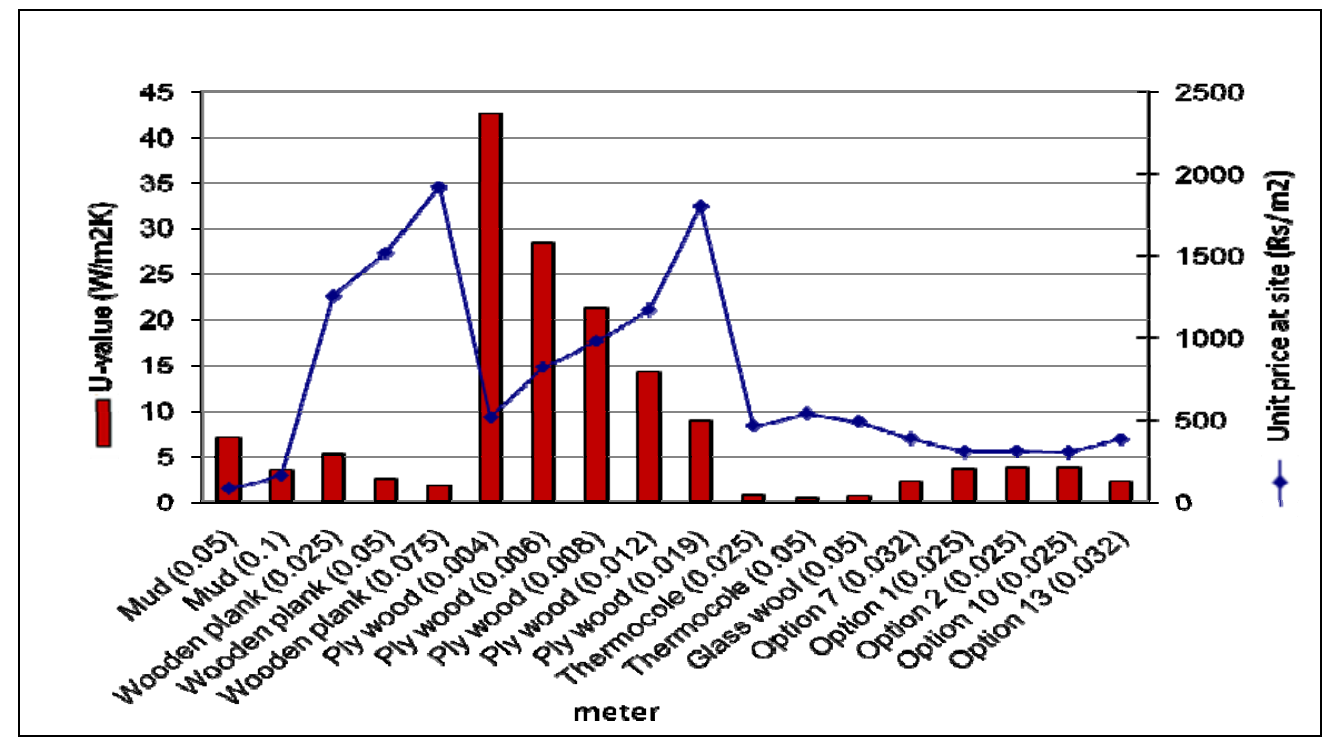

Figure 5.2: Comparison of U-value and Price of Different Insulation Materials

The energy consumption in the households could be reduced successfully by achieving a lower $\mathrm{U}$ - value at lesser costs using local materials provided that the tiles were produced on site. Materials like thermocole, glass wool, wooden planks, etc provide effective insulation but are very costly in such high altitudes solely due to transportation costs. These materials are also susceptible to fire hazards and have low life. Hence, insulation prepared from locally available materials, reused waste products, etc. could be exemplary both economically as well as environmentally.

\section{CONCLUSIONS}

Most of the energy is utilised for space heating as high altitude of Nepal has severe cold weather. Emission of pollutants from fuel wood and cattle dungs used for space heating can be reduced by increasing efficiency of the building. Locally available materials cum waste products can be used as building insulation cost effectively. Demand side management and renewable energy have a great potential in SNPBZ to mitigate the climate change impact as a local effort.

\section{ACKNOWLEDGEMENTS}

This study was conducted with the financial support from Ev-K2-CNR, Italy, under HKKH partnership and WWF Nepal. Sincere acknowledgements are also expressed to local people of SNPBZ for their understanding and kind co-operation to conduct the study.

\section{REFERENCES}

[1] Nepal S K (2008), "Tourism-induced rural energy consumption in Annapurna region of Nepal”, Tourism Management 29:89-100, Kathmandu, Nepal

[2] Prasad R, Maithel S, Mirza A (2001), "Renewable energy technologies for fuel-wood conservation in Indian Himalayan region", Sustainable Development 103-108 
[3] http://www.southderbys.gov.uk/environment/energy/energy_effciency/insulating_your home/default.asp (10 Jan 2008)

[4] Monthly tourist records at Jorsalle. Issued 2008 by research group at Monju SNPBZ.

[5] Bhochhibhoya, S. (2008) "Impact of Energy-Use on Climate Change: A Case study of energy-efficient existing buildings in Sagarmatha National Park" MSc. Dissertation, Department of Environmental Science and Engineering, Kathmandu University, Dhulikhel, Nepal

[6] Bhattari, G. P. (2010), "Managing Environment and Tourism in Sagarmatha National Park", www.evk2cnr.org/it/evk2ftp/bhattarai.doc

[7] Salerneo F.,Viviano G., Thakuri S., Flury B., Maskey R. K., Khanal S N., Bhuju D., Carrer M., Bhochhibhoya S., Melis M T., Giannino F., Staiano A., Carteni F., Mazzoleni S, Cogo A., Sapkota A., Shrestha S., Pandey R. K., and Manfredi C. E. (2010), “ Energy, Forest, and Indoor Air Pollution Models for Sagarmatha National Park and Buffer Zone, Nepal, Implementation of a Participatory Modelling Framework, Mountain Research and Development (MRD), An international, peer-reviewed open access journal published by the International Mountain Society (IMS), www.journal.org.

[8] Bhattacharya, S.C. and Abdul Salam, P. (2001), Low greenhouse gas biomass options for cooking in the developing countries, Energy Program, Asian Institute of Technology, School of Environment, Resources, and Development, Thailand.

[9] Bhochhibhoya S, Maskey R. K., Khanal S. N. and Pandey R. K. (2009), "Energy-Use Pattern in SNPBZ and Potentiality for Reducing Green-house Gas Emission", International Conference on Renewable Energy Technology for Sustainable Development (RETSUD-09), 12-14 November 2009, Kathmandu, Nepal

[10] Sulpya, K. M. and Bhadra, B. (1991), Study and Documentation of Stoves for Cooking and Space heating at High Altitudes in Nepal, Research Centre for Applied Science and Technology/ Centre for Economic Development and Administration, TU, Nepal.

[11] Maskey R K, Bhochhibhoya, Pandey R K, Khanal S N, Kayastha R, Kafle K, Salerno F, Flurry B and Viviano G (2010), "Energy Management Research in Sagarmatha National Park and Buffer Zone (SNPBZ) and its Outcomes", Contemporary Research in Sagarmatha (Mt. Everest) Region, Nepal: An Anthology, pp 57-64, Nepal Academy of Science and Technology, Kathmandu, Nepal.

[12] Dahal A and Kunwar U (2009), "Comparison of Household Energy- Use and Its Impact in Langtang National Park” BSc. Dissertation, Department of Environmental Science and Engineering, Kathmandu University, Dhulikhel, Nepal 